\title{
SPAWNING AND PARENTAL CARE IN Hoplias malabaricus (TELEOSTEI, CHARACIFORMES, ERYTHRINIDAE) IN THE SOUTHERN PANTANAL, BRAZIL
}

\author{
PRADO, C. P. A. ${ }^{1}$, GOMIERO, L. M. ${ }^{1}$ and FROEHLICH, O. ${ }^{2}$ \\ ${ }^{1}$ Departamento de Zoologia, Instituto de Biociências, Universidade Estadual Paulista, \\ C. P. 199, CEP 13506-900, Rio Claro, SP, Brazil \\ ${ }^{2}$ Departamento de Biologia/CCBS, Universidade Federal de Mato Grosso do Sul, \\ C. P. 549, CEP 79070-900, Campo Grande, Mato Grosso do Sul, Brazil \\ Correspondence to: Cynthia Almeida Prado, Departamento de Zoologia, Instituto de Biociências, \\ Universidade Estadual Paulista, C. P. 199, CEP 13506-900, Rio Claro, SP, Brazil, e-mail: cpap@ rc.unesp.br \\ Received May 21, 2004 - Accepted September 29, 2004 - Distributed May 31, 2006
}

(With 1 figure)

\begin{abstract}
Herein we describe spawning and egg guarding in the erythrinid fish Hoplias malabaricus observed in the southern Pantanal (19 34' S and 57 00' W), state of Mato Grosso do Sul, Brazil. Nests were depressions built on sandy soil in flooded areas, and contained a mean of 8,197 $\pm 2,204$ eggs $(\mathrm{N}=4)$; the mean diameter of eggs was $1.44 \pm 0.09 \mathrm{~mm}(\mathrm{~N}=400)$. Among 11 nests observed, eight were guarded by males and three by the pair. One male remained in the nest for six days, and two pairs remained guarding the eggs for at least three days before being captured. Females $(\mathrm{N}=2)$ captured in the nest contained oocytes in their ovaries. Our observations suggest that male parental care is the normal form of parental care in $H$. malabaricus, but biparental care also seems to occur.
\end{abstract}

Keywords: reproduction, parental care, Hoplias malabaricus, Erythrinidae, Pantanal.

\section{RESUMO}

\section{Desova e cuidado parental em Hoplias malabaricus (Teleostei, Characiformes, Erythrinidae) no Pantanal Sul, Brasil}

No presente estudo, descrevemos os comportamentos de desova e cuidado parental para um membro da referida família, Hoplias malabaricus, os quais foram observados no Pantanal sul (19 $34^{\circ}$ S e $57^{\circ} 00^{\prime} \mathrm{W}$ ), Estado de Mato Grosso do Sul, Brasil. As desovas foram observadas no início da cheia, depositadas em ninhos construídos em substrato arenoso em áreas alagadas. As desovas continham, em média, $8.197 \pm 2.204$ ovos $(\mathrm{N}=4)$; o diâmetro médio dos ovos foi de $1,44 \pm 0,09 \mathrm{~mm}(\mathrm{~N}=400)$. Entre 11 ninhos observados, oito foram guardados por machos e em três observamos o casal. Um macho permaneceu no ninho por seis dias, e dois casais foram observados por três dias no ninho até serem capturados. As fêmeas $(\mathrm{N}=2)$ capturadas nos ninhos continham óvulos nos ovários. O cuidado parental em Hoplias malabaricus é normalmente exercido pelos machos, mas nossas observações sugerem que o cuidado biparental pode ocorrer de forma facultativa.

Palavras-chave: reprodução, cuidado parental, Hoplias malabaricus, Erythrinidae, Pantanal.

\section{INTRODUCTION}

Egg guarding is the most common form of parental care in fish (Clutton-Brock, 1991), and in the majority of species that show parental care, only one parent is involved. Among teleost families, male care is much more common than female care, with $61 \%$ against $39 \%$, respectively, and biparental care occurs in less than $25 \%$ of the families with care (Gross \& Shine, 1981). Reduced egg predation and/or increased hatchability are proposed as the main benefits of egg guarding (Baylis, 1981). 
The Erythrinidae family consists of predatory and carnivorous fish, grouped into three genera: Hoplias, Hoplerythrinus, and Erythrinus (Quagio-Grassiotto et al., 2001). Some are airbreathers, being able to move from one lake to another on land (Nelson, 1994; Britski et al., 1999). Concerning reproduction, erythrinid species are characterized by external fertilization, nest building, and egg guarding; generally performed by males (Blumer, 1982).

Hoplias malabaricus (Bloch, 1794) is a member of the Erythrinidae family and is widely distributed in the Neotropical region (Matkovic \& Pisanó, 1989a). The species is well adapted to lentic environments, although it can also occur in small or large rivers. Individuals are generally found in pools (amidst the marginal vegetation), are cryptically colored, and capture prey by ambush (Uieda, 1984; Casatti et al., 2001). Furthermore, H. malabaricus shows multiple spawning and parental care (Caramaschi \& Godinho 1982; Araújo-Lima \& Bittencourt, 2001). However, previous studies do not report which sex is responsible for the care in $H$. malabaricus.

Herein we describe the spawning and parental care behaviors of $H$. malabaricus, known as "traíra" at the study site, in the floodplain of the south Pantanal, state of Mato Grosso do Sul, western Brazil.

\section{METHODS}

The study was conducted in the southern Pantanal, southwestern Brazil. The Pantanal is a great floodplain, with an area of $c a .140,000 \mathrm{~km}^{2}$, delimited mostly by the Paraguay river in the west and Brazilian uplands in the east (see Por, 1995). Observations and data collection were carried out in the municipality of Corumbá, state of Mato Grosso do Sul (19 $34^{\prime} \mathrm{S}$ and $\left.57^{\circ} 00^{\prime} \mathrm{W}\right)$ along the Miranda river, an important tributary of the Paraguay river. The region is characterized by a seasonal climate ("Aw" type in Köppen's classification), with a rainy summer from October to April and a dry winter from May to September. Annual floods are common along the Miranda system (Por, 1995), and generally occur at the study site from January to April. Savanna-like vegetation ("cerrado") predominates in the area and has patches of semi deciduous forests, gallery forests, and grassland fields.

The observations were made between 11 and 18 January, 2002. Subsequent to flooding, individuals of $H$. malabaricus were observed reproducing around the Base de Estudos do Pantanal/UFMS, a research station that offered us logistical support. The water depth was measured close to the nests to the nearest $0.1 \mathrm{~cm}$ with a measuring tape. Nests containing individuals were checked at least twice a day. Individuals were collected with fishhooks and meat as bait. Afterwards, they were preserved in $10 \%$ formalin, and dissected for sex identification. The total body length (TL) was measured to the nearest $1 \mathrm{~mm}$ with a plastic ruler. Some clutches were collected and immediately preserved in $5 \%$ formalin; the number of eggs per clutch was determined and the egg diameter was measured with an ocular micrometer under a stereomicroscope $( \pm 0.1 \mathrm{~mm})$. We have used all occurrences sampling method (Altmann, 1974) to describe spawning and nest guarding behaviors.

\section{RESULTS}

\section{Nests and clutches}

Nests of $H$. malabaricus were observed in flooded areas along the Miranda river. Reproduction began approximately 30 days after the flood had arrived at the study site. A total of 11 nests containing eggs were found where the mean water depth was $17.9 \pm 6.0 \mathrm{~cm}$ (range $=10-29 ; \mathrm{N}=11$ ), and the water was clean and transparent. The nests were depressions similar to basins built on sandy soil, with a clean bottom, containing no vegetation or debris. The format of the depressions was approximately circular with a diameter of about $10 \mathrm{~cm}$ and $3 \mathrm{~cm}$ deep. Clutches examined contained a mean of $8,197 \pm 2,204$ eggs $($ range $=5,380-10,768 ; \mathrm{N}=4$; Table 1$)$; the mean diameter of eggs was $1.44 \pm 0.09 \mathrm{~mm}(\mathrm{~N}=400$ eggs from four clutches). All the eggs in each nest observed $(\mathrm{N}=11)$ were in the same developmental stage. Eggs were yellowish colored; the clutches formed a compact mass of eggs, but were not adhered to the nest bottom. The first nest was observed on 11 January, but half of the nests were found four days later (Table 1). By 18 January 2002, our field 
TABLE 1

Summary of data on nests of Hoplias malabaricus in the southern Pantanal during January 2002. M, male; F, female; a, sex identified by dissection; b, sex suggested by observations; and c, sex identified by spawning observation.

\begin{tabular}{|c|c|c|c|c|c|}
\hline Date & Nest & Sex Guarding & Total length $(\mathrm{mm})$ & N Eggs per clutch & Mean $( \pm$ SD) egg diameter $(\mathrm{mm})$ \\
\hline 11 Jan & 01 & $\mathrm{M}_{\mathrm{a}}$ & 230.0 & 10,768 & $1.42 \pm 0.10(\mathrm{~N}=100)$ \\
\hline 12 Jan & 02 & $M_{c}$ & - & - & - \\
\hline 12 Jan & 03 & $\begin{array}{l}M_{b} \\
F_{a} \\
\end{array}$ & $\begin{array}{c}- \\
265.0 \\
\end{array}$ & - & - \\
\hline 12 Jan & 04 & $\begin{array}{l}\mathrm{M}_{\mathrm{a}} \\
\mathrm{F}_{\mathrm{b}}\end{array}$ & $\begin{array}{c}320.0 \\
- \\
\end{array}$ & - & - \\
\hline 14 Jan & 05 & $\mathrm{M}_{\mathrm{a}}$ & 215.0 & 5,380 & $1.44 \pm 0.07(\mathrm{~N}=100)$ \\
\hline 14 Jan & 06 & $\mathrm{M}_{\mathrm{c}}$ & - & - & - \\
\hline 15 Jan & 07 & $\mathrm{M}_{\mathrm{a}}$ & 210.0 & 8,288 & $1.49 \pm 0.07(\mathrm{~N}=100)$ \\
\hline $15 \mathrm{Jan}$ & 08 & $\mathrm{M}_{\mathrm{b}}$ & - & - & - \\
\hline 15 Jan & 09 & $\mathrm{M}_{\mathrm{a}}$ & 220.0 & - & - \\
\hline 15 Jan & 10 & $\mathrm{M}_{\mathrm{b}}$ & - & - & - \\
\hline 16 Jan & 11 & $\begin{array}{l}\mathrm{M}_{\mathrm{a}} \\
\mathrm{F}_{\mathrm{a}}\end{array}$ & $\begin{array}{l}255.0 \\
215.0\end{array}$ & 8,352 & $1.40 \pm 0.09(\mathrm{~N}=100)$ \\
\hline
\end{tabular}

work had finished, and when we returned to the study site, about 20 days later, the reproduction had already finished.

\section{Spawning behavior and parental care}

Three pairs of $H$. malabaricus were observed spawning during the morning. In the first case, observed on 12 January, 2002 between $9 \mathrm{~h}$ and 10 h 30 (Nest \# 2 in Table 1), the spawning was in course, and when finished the male remained on the nest while the female went away. The male and female could be distinguished because of the female's position during oviposition. The nest was checked at least twice during the day and night, and the male remained on the nest for six days, up to 18 January, 2002. The male protected the eggs aggressively against other fish and observers that tried to approach. The second spawn occurred ca. $30 \mathrm{~m}$ from the first nest, on 14 January, 2002, between 8 h 40 and 9 h 10 (Nest \# 6 in Table 1). The bodies of the pair were positioned side by side, heads toward the same side, and the male tried to approach its vent to the female's vent. By the end of oviposition, the male remained on the nest and the female went away. The male was observed close to the nest in the two subsequent days, protecting the eggs from other fish. The third spawning was observed on 16 January, 2002 (Nest \# 11 in Table 1). The pair was first observed at $8 \mathrm{~h} 45$, before spawning, trying to expulse the male that was guarding the eggs in the nest described above (Nest \# 6). When the pair finally expulsed the male,

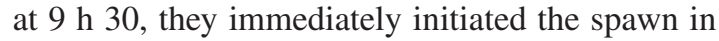
a nest previously constructed $c a .70 \mathrm{~cm}$ from the nest \# 6. Before oviposition, the male touched the female with its head and body, then the spawn occurred in a similar way described above, finishing at $10 \mathrm{~h} \mathrm{10.} \mathrm{Afterwards,} \mathrm{the} \mathrm{male} \mathrm{and} \mathrm{the} \mathrm{female}$ remained close to the nest. The expulsed male from the nest \# 6 returned to its nest approximately 40 min later, but was aggressively pursued by both the male and female that had recently spawned in nest \# 11. The guarding male from nest \# 6 ended up abandoning the nest, which by that time had the eggs almost totally predated by other fish.

Of the 11 nests studied, in eight we observed one individual close to the nest (Fig. 1) and in three we observed two individuals close to the nest. The eight solitary individuals were males and behaved aggressively against observers and fish that tried to approach the nests (Table 1). Four individuals were collected and dissected for gonad observation and sex identification, two were identified as males by spawning observation, and doubts remained about the other two individuals. In two nests where two individuals were observed, the nests were regularly checked, and they actively guarded the eggs for at least three days before the capture of one of the 


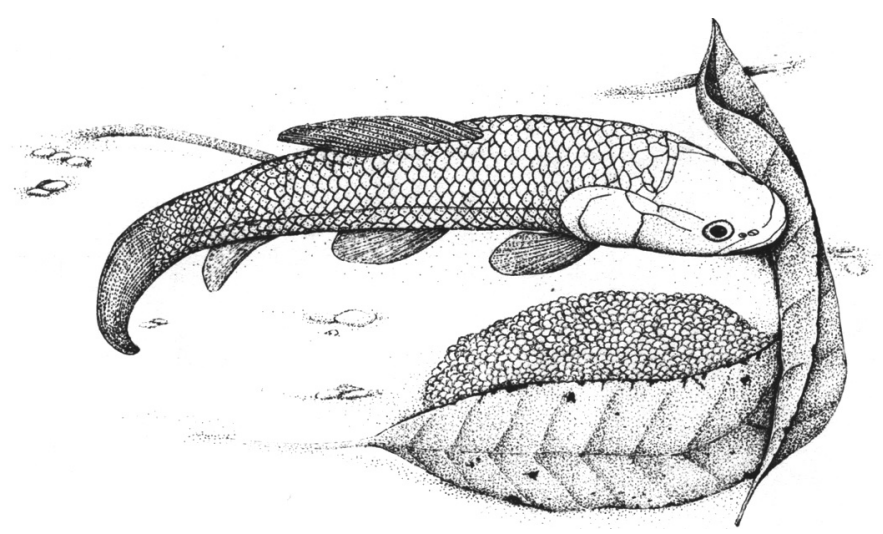

Fig. 1 - Male Hoplias malabaricus guarding eggs deposited in a basin in the southern Pantanal, Brazil. Drawn after slides.

individuals (Nests \# 3 and 4 in Table 1). In nest \# 3, the individual captured was a female, so we suggest that the other was the male. In nest \# 4, the individual captured was the male, so the other could be the female. The third nest where two individuals were observed was that where the pair's spawning and pursuit behaviors were described above (Nest \# 11). Both individuals were captured $24 \mathrm{~h}$ after spawning, dissected as the others, and one was a female and the other a male. In these three cases, one individual was always on the nest and the other around $1.0 \mathrm{~m}$ from the nest; individuals captured on the nests were always males and those close to them were females. When dissected, females performing parental care contained oocytes in different developmental stages. The mean total length of captured males was $241.7 \pm 41.5 \mathrm{~mm}$ (range $=210-320, \mathrm{~N}=6$ ) and the two captured females attained a total length of 215 and $265 \mathrm{~mm}$ (Table 1).

\section{DISCUSSION}

In the present study, $H$. malabaricus was observed reproducing in the Pantanal at the beginning of the flooding season, constructing nests, spawning, and guarding eggs in flooded areas. This species is known to show multiple spawning in the Venezuelan rivers (Machado-Allison, 1990), which are generally synchronized with periods of floods, and also builds nests and guards eggs in flooded areas, but which sex is responsible for egg attendance is not mentioned. Other studies, conducted in different regions throughout South America, showed that the period of reproduction is variable for the species. Reproduction may occur during months of high rainfall in some sites (e.g., state of São Paulo, Brazil, Caramaschi \& Godinho, 1982; Barbieri, 1989; Argentina, Matkovic \& Pisanó, 1989b; Domanico et al. 1993; central Amazonia, Brazil, Araújo-Lima \& Bittencourt, 2001; State of Paraíba, Brazil, Marques et al., 2001), such as the data registered in this study for the south Pantanal, but also during periods of drought and lower temperatures in other regions (upper Paraná river floodplain, States of Paraná and Mato Grosso do Sul, Brazil, Bialetzki et al., 2002).

As observed in the present study, in central Amazonia the yellowish eggs are also deposited in shallow water ( $\sim 15 \mathrm{~cm}$ deep), close to aquatic vegetation, in saucer-format nests, forming an adherent mass of eggs (Araújo-Lima \& Bittencourt, 2001); eggs are adhered to each other due to the presence of a specific glicoprotein (Matkovic \& Pisanó, 1989c). Previous studies showed that the total length of females of $H$. malabaricus at first reproduction could vary from $141.0 \mathrm{~mm}$ (Oliveira \& Nogueira, 2000) to $230.0 \mathrm{~mm}$ (Barbieri, 1989), the mean diameter of mature oocytes was $1.75 \mathrm{~mm}$, and the number of mature oocytes could vary from 6,446 to 14,131 (Araújo-Lima \& Bittencourt, 2001). These values differ from those recorded for the species in the present study. An explanation could be related to population differences, or alternatively due to taxonomic problems; these studies may involve more than one species currently identified as H. malabaricus (J. C. Garavello, pers. comm.). 
Male parental care was more frequently observed in $H$. malabaricus in the Pantanal in the present study. The Erythrinidae family is distinguished by showing male parental care of eggs (Blumer, 1982), but the author did not cite the species presenting male parental care. Moreover, in prior studies on $H$. malabaricus it is not clear which parent provides parental care (Caramaschi \& Godinho, 1982; Machado-Allison, 1990; AraújoLima \& Bittencourt, 2001). Thus, this study is the first to describe parental care in detail for H. malabaricus. Male parental care is much more frequent among bony fish (Clutton-Brock, 1991); among external fertilizers with parental care, about $76 \%$ of cases involve males, which commonly defend territories used by several females in succession (e. g., Williams, 1975; Ridley, 1978; Gross \& Sargent, 1985). Three different hypotheses have been proposed to explain which parent is selected to care: 1) "gamete-order" (Dawkins \& Carlisle, 1976; Ridley, 1978); 2) "reliability of paternity" (Trivers, 1972; Ridley, 1978); and 3) "parent-offspring association" (Williams, 1975). Gross \& Shine (1981) tested the three hypotheses and showed that the association hypothesis was the most consistent with the available data. The authors also suggested that the prevalence of paternal care in external fertilizers resulted from male territoriality. Taking this into account, along with territoriality, the presence of multiple spawning was important in the evolution of male parental care because males that defend sites of spawning against other males indicate higher chances of reproducing again (Blumer, 1979). Hoplias malabaricus is known to show male territoriality and multiple spawning (Barbieri, 1989), which are consistent to the presence of male parental care.

In the present study, along with paternal care, we suggest the occurrence of biparental care of eggs in three of the 11 nests of $H$. malabaricus which were observed. Biparental care is rare among teleost fishes, occurring in approximately $13 \%$ of the external fertilizer families (Gross \& Shine, 1985), and is unusual where care-taking is limited to eggs (Blumer, 1979). However, multiple patterns of parental care (no care, male care, biparental care, or female care) are known to occur within a single population during a single breeding season in many groups of animals, including fish (Webb et al., 1999). Benefits associated with biparental care generally are the increase of offspring protection against predators and the possibility of one partner to assume care if the other dies or deserts (Annett et al., 1999). For example, females of the ictalurid fish Ictalurus nebulosus commonly remain in the vicinity of their brood, though males are primarily responsible for care (Blumer, 1986). However, if the male disappears, the female takes over the male's role. In the case of $H$. malabaricus herein described, although we did not notice a partner in the vicinity of eight of the 11 nests, we can not exclude this possibility. As females of this species show multiple spawns, and females captured contained oocytes, alternative explanations for the presence of the female close to the nest could be that females were waiting for those partners to spawn later or for favorable sites for oviposition. Our observations suggest that male parental care is the normal form of parental care in H. malabaricus, but biparental care could also occur. Further observations in spawning and parental care behaviors of H. malabaricus in the Pantanal and other regions are needed.

Acknowledgments - We are grateful to C. F. B. Haddad, M. Uetanabaro, and F. M. S. Braga for critically reading the manuscript and for the valuable suggestions, P. Landgref Filho and E. Amorim for field assistance, PROPP - Base de Estudos do Pantanal - UFMS for the facilities and logistical support, and J. R. Somera for the drawings. C. P. A. Prado acknowledges $\mathrm{CNPq}$ for financial support (proc. 521746/97-3/NV) and graduate fellowship $(140397 / 2000-0)$. C. P. A. Prado also thanks FAPESP for financial support (proc. 04/00709-0 and 01/13341-3).

\section{REFERENCES}

ALTMANN, J., 1974, Observational study of behavior: sampling methods. Behaviour, 15: 227-267.

ANNETT, C. A., PIEROTTI, R. \& BAYLIS, J. R., 1999, Male and female parental roles in the monogamous cichlid, Tilapia mariae, introduced in Florida. Env. Biol. Fishes, 54: 283-293.

ARAÚJO-LIMA, C. A. R. M. \& BITTENCOURT, M. M., 2001, A reprodução e o início da vida de Hoplias malabaricus (Erythrinidae: Characiformes) na Amazônia Central. Acta. Amazônica, 31(4): 693-697.

BARBIERI, G., 1989, Dinâmica da reprodução e crescimento de Hoplias malabaricus (Bloch, 1794) (Osteichthyes, Erythrinidae) da represa do Monjolinho, São Carlos/SP. Rev. Brasil. Zool., 6(2): 225-233.

BAYLIS, J. R., 1981, The evolution of parental care in fishes, with reference to Darwin's rule male sexual selection. Env. Biol. Fishes, 6: 223-251.

BIALETZKI, A., NAKATANI, K., SANCHES, P. V. \& BAUMGARTNER, G., 2002, Spatial and temporal distribution of larvae and juveniles of Hoplias aff. 
malabaricus (Characiformes, Erythrinidae) in the upper Paraná river floodplain, Brazil. Braz. J. Biol., 62(2): 211-222.

BLUMER, L. S., 1979, Male parental care in the bony fishes. Quart. Revie. Biol., 54: 149-161.

BLUMER, L. S., 1982, A bibliography and categorization of bony fishes exhibiting parental care. Zool. J. Lin. Soc., 76: $1-22$.

BLUMER, L. S., 1986, Parental care sex differences in the brown bullhead Ictalurus nebulosus (Pisces, Ictaluridae). Behav. Ecol. Sociobiol., 19: 97-104.

BRITSKI, H. A. (ed.), SILIMON, K. Z. \& LOPES, B. S., 1999, Peixes do Pantanal, Manual de Identificação. EMBRAPASPI, Brasília, 184p.

CARAMASCHI, E. P. \& GODINHO, H. M., 1982, Reprodução de Hoplias malabaricus (Bloch, 1794) (Teleostei, Erythrinidae) na represa do rio Pardo (Botucatu-SP). Histologia e escala de maturação do ovário. Rev. Brasil. Biol., 42(3): 635-640.

CASATTI, L., LANGEANI, F. \& CASTRO, R. M. C., 2001, Peixes de riacho do Parque Estadual Morro do Diabo, bacia do alto rio Paraná, SP. Biota Neotropica, 1: 1-15.

CLUTTON-BROCK, T. H., 1991, The evolution of parental care. Princeton University Press, Princeton, New Jersey, USA, 352p.

DAWKINS, R. \& CARLISLE, T. R., 1976, Parental investment, mate desertion and a fallacy. Nature, 262: 131-133.

DOMANICO, A., DELFINO, R. \& FREYRE, L., 1993, Edad y crecimiento de Hoplias malabaricus malabaricus (Bloch, 1794) (Teleostei, Erythrinidae) en la laguna de Lobos (Argentina). Iheringia, 74: 141-149.

GROSS, M. R. \& SHINE, R., 1981, Parental care and mode of fertilization in ectothermic vertebrates. Evolution, 35(4): 775-793.

GROSS, M. R. \& SARGENT, R. C., 1985, The evolution of male and female parental care in fishes. Amer. Zoolog., 25: $807-822$.

MACHADO-ALLISON, A., 1990, Ecología de los peces de las areas inundables de los llanos de Venezuela. Interciencia, 15: 411-423.

MARQUES, D. K. S., GURGEL, H. C. B. \& LUCENA, I., 2001, Época de reprodução de Hoplias malabaricus Bloch, 1794,
(Osteichthyes, Erythrinidae) da barragem do rio Gramame, Alhandra, Paraíba, Brasil. Rev. Bras. Zooc., 3(1): 61-67.

MATKOVIC, M. \& PISANÓ, A., 1989a, Estúdio macro y microscopico del desarrollo de Hoplias m. malabaricus (Pisces, Erythrinidae). I: Fase Larval. Rev. Brasil. Biol., 49(2): 553-569.

MATKOVIC, M. \& PISANÓ, A., 1989b, Final maturation and ovulation provoked by suplí of homologous hypophysis in Hoplias m. malabaricus (Pisces, Erythrinidae). Rev. Brasil. Biol., 49(1): 213-220.

MATKOVIC, M. \& PISANÓ,A., 1989c, Oogenesis and ovulation in normal conditions or induced by homologous hypophysis in Hoplias m. malabaricus (Pisces, Erythrinidae). Rev. Brasil. Biol., 49(1): 203-212.

NELSON, J. S., 1994, Fishes of the world. John Wiley, New York, USA. 600p.

OLIVEIRA, R. D. \& NOGUEIRA, F. M. de B., 2000 , Characterization of the fishes and of subsistence fishing in the Pantanal of Mato Grosso, Brazil. Rev. Brasil. Biol., 60(3): 435-445.

POR, F. D., 1995, The Pantanal of Mato Grosso (Brazil): World's largest wetlands. Kluwer Academic Publishers, Dordrecht, The Netherlands, 122p.

QUAGIO-GRASSIOTTO, I., NEGRÃO, J. N. C., CARVALHO, E. D. \& FORESTI, F., 2001, Ultrastructure of spermatogenic cells and spermatozoa in Hoplias malabaricus (Teleostei, Characiformes, Erythrinidae). J. Fish Biol., 59: 1494-1502.

RIDLEY, M., 1978, Paternal care. Anim. Behav., 26: 904-932.

TRIVERS, R. L., 1972, Parental investment and sexual selection. In: B. Campbell (ed.), Sexual selection and the descent of man: 136-179. Aldine Publishing Company, Chicago, USA.

UIEDA, V. S., 1984, Ocorrência e distribuição dos peixes em um riacho de água doce. Rev. Brasil. Biol., 44(2): 203-213.

WEBB, J. N., HOUSTON, A. I., MCNAMARA, J. M. \& SZÉKELI, T., 1999, Multiple patterns of parental care. Anim. Behav., 58: 983-993.

WILliaMS, G. C., 1975, Sex and evolution. Princeton University Press, Princeton, New Jersey, USA. 210p. 